\title{
The Gametophytes and Embryo of Sciadopitys verticillata.
}

\author{
BY
}

\author{
A. Anstruther LAWSON, Ph.D., F.R.S.E. \\ Lecturer in Botany, the University of Glasgow.
}

\section{With Plates XXIX-XXXI.}

$\mathrm{O}^{\mathrm{u}}$ UR knowledge of the gametophytes and embryo of Sciadopitys is very meagre, consisting essentially of a brief and fragmentary account of the mature archegonium and embryo published by Professor W. Arnoldi in I90I, and Thomson's description of the megaspore membrane. I have thought it worth while to prepare a fuller account of the developmental stages in connexion with the gametophytic structures, fertilization, and embryo of this interesting genus, in the hope of filling a gap in our knowledge of the Coniferales as a whole.

All of the material for this investigation was obtained from young trees growing in the Pinetum of the Royal Gardens, Kew. For facilities afforded in collecting material and also preparing it in the Jodrell Laboratory, I am much indebted to the Director, Lieut.-Col. Prain, F.R.S. I am also very much indebted to Mr. L. A. Boodle, F.L.S., for many kindnesses. Circumstances did not permit of my remaining at Kew sufficiently long to obtain all of the necessary material, but Mr. Boodle was kind enough to send me living cones from time to time; without this help many of the interesting stages would, of necessity, have been omitted.

\section{The Male Gametophyte.}

From the material collected at Kew Gardens it appears that the microspores mature early in April, and pollination occurs between two and three weeks later. At maturity the microspores have a very thick, hard, resistent exine or exospore, and a well-developed but thin endospore. The thick, hard, outer membrane offered such resistance to the knife in cutting that it was impossible to obtain very thin sections of the microspores. Sections, however, were obtained sufficiently thin to make out all of the essential details. As shown in P1. XXIX, Figs. I, 2, 3, and 4, the endosporium appears to be very thick, but this appearance is due to the 
fact that the sections here represented are not median. The inner membrane, seen in transverse section, is in reality quite thin. The microspores themselves are not exactly spherical in form, they are slightly elongated or egg-shaped. At one end of the long axis the exospore becomes sharply attenuated, and at the end of the spore it is very thin. This peculiarity of the spore-wall is indicated in Figs. 2, 3, and 4.

The contents of the mature spore consist of a large centrally placed nucleus suspended in a rather dense granular cytoplasm, as shown in Fig. I. The stage here figured is one just preceding the germination of the spore, for its nucleus is obviously preparing for mitosis. In Fig. 2 is represented the first spindle in the germinating microspore, the chromosomes being at the equatorial plate. Fig. 3 represents a later stage with the chromosomes at the poles of the spindle. It will be observed from Figs. 2 and 3 that the long axis of the spindle is parallel with the long axis of the spore, and consequently one of the cells resulting from this division will find itself placed directly behind the weak spot in the spore-wall. The result of this first division of the germinating spore is represented in Fig. 4. The daughter-nuclei are seen to be separated from one another by a delicate membrane, so that there are now two cells organized.

This division of the microspore takes place within the microsporangium, and it is the only division which occurs before pollination. In fact no other divisions occur until the pollen-tube is formed. Unlike the Abietineae (Coulter and Chamberlain, '01; Ferguson, '04; Lawson,'09) and Podocarpus (Coker, '02), there is not a trace of vestigial prothallial cells, and therefore the two cells that are formed are to be regarded as the generative cell and tube-cell respectively. At the time of pollination the pollen-grain is in the condition represented in Fig. 4. The grain is slightly oval in form, with the tube-cell in touch with the thin part of the exospore.

The young ovules, among the Coniferales, show a considerable variety of special adaptations in the form of devices for receiving the wind-conveyed pollen. In many of the Cupressineae which I have observed, the micropyle, at the time of pollination, exudes a small globule of transparent liquid. The purpose of this is no doubt to catch the pollen more effectively, and as the liquid evaporates the pollen-grains descend into the micropyle and find themselves lodged upon the apex of the nucellus. I have observed practically the same thing in Cephalotaxus and Taxus. In Pinus the integument of the young ovule extends outwards in the form of two free limbs which, upon receiving the pollen, curve towards one another, and the grains are thus led into the micropylar canal. In Pseudotsuga (Lawson, '09), on the other hand, the pollen-grains are caught in the stigmatic surface of hair-like structures at the lip of the micropyle, and here they germinate, sending down the pollen-tubes through the micropylar canal. The grains themselves in this case never reach the nucellus. In 
Sciadopitys there is a specialized pollen-receiving device which is quite unlike any of these. At the time of pollination the integument extends but very slightly above the surface of the nucellus, in such a fashion as to form a wide gaping but shallow micropyle. Shortly before the pollen is shed, the upper part of the nucellus becomes sharply differentiated into an organ which, for convenience, I will call the pollen-cushion. This cushion consists of comparatively large cells with intercellular spaces, and with thin cell-walls forming a loose soft tissue which stands out in sharp contrast against the small-celled firmer tissue of the nucellus below. These cushioncells secrete at the surface a transparent liquid substance, which, from an examination of the fresh ovules, appeared to be more refractive and more dense than water. This pollen-cushion, therefore, not only serves as a stigmatic surface for receiving the pollen, but also furnishes a soft loose tissue into which the young pollen-tubes may penetrate with very little resistance.

Now, while such special adaptations as these pollen-receiving devices may not be of direct phylogenetic importance, they are nevertheless very interesting. They show a series of modifications of structure which probably followed close upon the adoption of the pollen-tube as a means of conveying the sperm-nuclei into the egg.

In Sciadopitys the pollen-cushion is ready to receive the pollen early in April, and, as stated above, the integument at this time projects very slightly above the surface, forming a wide micropyle into which the pollen is blown by the wind. During the latter half of April numbers of pollengrains were found in this position. In some ovules but one or two grains were found, while in others the micropyle was crowded full of them. A few of them are shown in Fig. 6.

The next step in the germination of the microspore was its rapid enlargement and the casting off of the exospore. This takes place immediately after the pollen-cushion has been reached. These changes are shown in Fig. 5. Meantime, the integument continues its growth forward, as may be seen in Fig. 6, and the micropyle is gradually closed. The complete closure of the micropyle occupies about three weeks. During this period the pollen-tubes have made their appearance, and have penetrated for some considerable distance into the tissue of the pollen-cushion.

Although the pollen-tube has attained a considerable length, no nuclear activities occur until the middle of June. About this time the generative nucleus divides, giving rise to a large, more or less, spherical cell with a distinct cell membrane and a free nucleus. These structures, by their later behaviour, were readily identified as the body-cell and the stalknucleus. Their position and relative size may be easily made out in Fig. 8, which represents a longitudinal section of the pollen-tube immediately after the division of the generative cell. It will also be seen from this figure that these two structures remain for some time in the spore end of 
the tube, while the tube-nucleus advances with the growing tip. Early in July, however, the stalk-nucleus follows in the wake of the tube-nucleus down the tube, leaving the body-cell in its original position in the spore end. This shifting of the free nuclei in the tube is shown in Figs. 9 and 10. As the tubes grow almost in a straight line down through the soft tissue of the pollen-cushion, no difficulty was met with in obtaining complete longitudinal sections showing all the essential changes during their development. In Fig. 7 is represented the general course of the tube as it appeared three months after pollination. As shown in Figs. 9 and 10, there are large numbers of starch grains in the cytoplasm of the tube, and the amount increases as development advances.

Up till this time the male gametophyte has undergone an uninterrupted development, so that about the middle of July we find the body-cell and the stalk-nucleus fully organized, and the pollen-tube lying embedded in the soft tissue of the pollen-cushion. And in this condition it remains until the following spring. Occasionally it was observed that the tube may penetrate for a short distance into the firmer tissue of the nucellus below the cushion, but this was quite exceptional. No further nuclear changes take place in the tube until eleven months later. In this regard the male gametophyte of Sciadopitys shows a marked resemblance to Pinus (Coulter and Chamberlain, '01; Ferguson, '04), but is quite unlike Cephalotaxus (Lawson, '07), which also takes two seasons before fertilization is accomplished, but where the pollen remains practically dormant for a year after pollination.

Early in June of the following year-that is, about fourteen months after pollination-the body-cell in Sciadopitys gradually descends into the tube, and finally occupies a position near the tip a little distance behind the stalk- and tube-nuclei. But during this migration of the body-cell the tube has not only penetrated the entire nucellar tissue, but has reached one of the archegonial chambers. In number and position those chambers resemble those of Pinus, but are very much deeper. In Fig. 48 the bodycell is represented in the region just entering the archegonial chamber, while the tip of the tube has reached the neck-cells. Fig. II shows, with the details more highly magnified, a portion of the pollen-tube containing the body-cell. In its descent in the tube the body-cell loses its spherical form and appears considerably elongated. It retains, however, its distinct membrane which separates it from the cytoplasm of the tube. The nucleus is very large and perfectly spherical, and as it approaches the tip of the tube it shows evidences of preparing for mitosis. The spindle of this division was not found, but several tubes showed the stages immediately following mitosis. The division of the body-cell evidently takes place in the tip of the tube immediately over the neck-cells of the archegonium, and it results, not in the formation of two cells as in Sequoia and the 
Cupressineae, but in two free nuclei. From the large number of cases examined showing these stages, it became quite evident that there was no cell membrane separating these two male nuclei from one another. The two structures were found lying quite freely in the cytoplasm of the bodycell, as shown in Fig. 12, and one of them is slightly but distinctly larger than the other. Both of them are carried through the neck-cells and into the archegonium by the tip of the tube. In two cases they were found lying in the egg cytoplasm just below the neck-cells. One of these is represented in Fig. 49.

\section{The Female Gametophyte.}

The number of ovules produced on each ovuliferous scale is quite large. They varied from five to fifteen or more according to the position of the scale on the cone, the lower scales producing the larger number, and decreasing as the scales became smaller towards the apex of the cone. They first appear as minute papillae-like structures growing out at right angles to the dorsal surface near the base of the scale, and arranged in two or three rows more or less crowded together. The nucellus or sporangium proper is the first to develop, but this is very soon followed by the integument, which, in the earlier stages, appears as a ring of tissue surrounding the base of each papilla-like nucellus. This condition was found early in March, and from this time on a complete series of stages was obtained by collecting material every two or three days. The ovules take about four weeks in their development before they are in a condition to receive the pollen. During this period the integument grows a little more rapidly than the sporangium, so that at the time of pollination it projects a little beyond the level of the apex of the latter.

The sporogenous tissue does not become differentiated until after the pollen has been received in the micropyle. Fig. 6 represents a longitudinal section of an ovule about three weeks after pollination. Although, as here shown, the pollen-cushion has been differentiated and the pollen received, and the micropyle nearly closed, there is as yet no trace of sporogenous tissue in the megasporangium. Except for the highly differentiated character of the pollen-cushion all of the cells of the nucellus resemble one another. During the last week in May, however, certain cells, deep in the centre of the nucellus at a point level with the insertion of the integument, become enlarged and take on a sporogenous character. These cells are few in number, and in one or two cases appeared singly. Whether they could always be traced back to a single cell I am unable to state, but it seems probable. These cells are not only large and with deeply staining nuclei, they are also actively merismatic. They divide rapidly and frequently, and soon give rise to a large and sharply differentiated sporogenous group 
which I interpret to be the archesporium. In the early stages of the group, that is when it consists of four or eight cells, the individual cells appear to be exactly alike, being quite large with dense granular cytoplasm and deeply staining nuclei, and stand out in sharp contrast to the surrounding smaller sterile cells. About this time, however, the most centrally situated cell of the young archesporial group enlarges and becomes differentiated into a functional megaspore-mother-cell. This cell not only differs from the other archesporial cells by its large size, but also by the presence of numerous starch grains in its cytoplasm which were not found in any of its neighbours. Theśe facts are well brought out in the longitudinal section of the sporangium represented in Fig. I5. Here it will be seen that the mother-cell lies in the centre of a large group of sporogenous cells located deep in the tissue of the nucellus.

It should be noted that the form of the sporangium is unusual. The ovules being quite numerous, they become crowded and closely packed together. The nucellus consequently takes on a flattened form, its breadth in transverse section being just about twice its width, as may be seen in Fig. 14. Another interesting point is brought out in this figure, namely, that the insertion of the integument is not at the same level around the base of the nucellus. This insertion is much higher up, at the narrower side of the flattened nucellus. This arrangement obviously gives strength to that region of the nucellus in which the sporogenous tissue is developing. I have not observed this in any other coniferous ovule.

As above stated, there is but a single functional megaspore-mothercell differentiated out of the sporogenous group. There was no evidence to show that its origin was any different from that of the other archesporial cells which surround it. And although the latter continue their merismatic activity for some time, there is no reason to regard them as other than sporogenous. They eventually develop into a large group of nourishing tapetal cells which completely surrounds the megaspore. This group of cells is, therefore, as in Pseudotsuga (Lawson, '09), tapetal in function and archesporial in origin. It persists for about a year, but is finally absorbed at the time of the formation of the permanent prothallial tissue.

I was fortunate enough to obtain a fairly complete series of stages showing all the essential points in connexion with the reduction division of the megaspore-mother-cell. In the first place, this cell is easily detected by its large size, by the presence of starch grains in its cytoplasm, and by its relatively large and deeply staining nucleus. The latter body, even in the resting stage, is much larger than any of the tapetal nuclei. The chromatin in the resting condition consists of delicate threads which interlace with one another, giving the appearance of a reticulum. There is always present at least one large nucleolus. As division approaches, the chromatin threads become more sharply defined, and what appeared to be 
a reticulum is really the effect of the separate threads interlacing and crossing with one another. This condition is shown in Fig. 17 .

During these changes in the chromatin there is a gradual enlargement of the nuclear cavity, presumably resulting from the increase in the amount of nuclear sap. As shown in Fig. 18, with the enlargement of the nuclear cavity the reticulated nature of the chromatin becomes completely lost, and the individual threads of which it is composed become sharply visible. A somewhat similar stage is shown in Fig. I9, but here the threads are isolating themselves from one another, and are spreading out into the enlarged nuclear cavity. It may be seen also from this figure that the chromatin threads are finely granular. The separation of the threads from one another continues until they are quite evenly distributed through the nuclear sap, and, as shown in Fig. 20, the threads become shorter and thicker, and their granular nature becomes more pronounced. This shortening and thickening of the threads proceeds rapidly until we finally have the appearance represented in Figs. 2I and 22. A large number of preparations were made at this time showing all intermediate stages as well as those here figured. In none of them was I able to find any evidence that the chromatin consisted of a continuous thread. In fact, all of the evidence seemed to indicate the opposite, namely, that the number of chromatin threads in the early stages correspond with the number of chromosomes into which they later develop. And I am strongly of the opinion that this is also true for the resting stage of the nucleus.

$\mathrm{Up}_{\mathrm{p}}$ to the stage represented in Fig. 22, there was no evidence of the reduction in the number of threads having taken place. In fact, in Fig. 23, which is undoubtedly a later stage than those represented in Figs. $2 \mathrm{I}$ and 22, we still find the diploid number. But at the stage shown in Fig. 23, there was some evidence of the actual fusion and consequent reduction of the chromosomes beginning to take place; and while the actual fusion was not followed with certainty, the reduced number always appeared after this stage and never before. In Fig. 24 is represented a slightly later stage, which I interpret to be immediately after or during the actual fusion of the chromosomes in pairs.

This stage is almost immediately followed by the disappearance of the nuclear membrane, the separation of the paired chromosomes from one another, and the formation of the reduction spindle. The spindle fibrils originate out of the cytoplasm after the manner which prevails throughout the flowering plants. An early stage of their development is shown in Fig. 25, with the reduced number of heterotype chromosomes lying freely in the cytoplasm and attached to the growing spindle fibrils. The spindle in the early stages is multipolar, but very soon becomes bipolar. The poles are at first quite broad, but later become sharply pointed (Figs. 26 and 27). After repeated counting the reduced number of chromosomes appeared to 
be eight, being just half the sporophyte number, which was easily and much more frequently estimated to be sixteen. Fig. 28 represents a transverse section of the mother-cell in a plane through the equatorial plate, showing the eight heterotype chromosomes as they appear in polar view. The daughter chromosomes now pass to the poles in the usual way, as shown in Fig. 29, and after being more or less crowded together, where it is difficult to identify the individual chromosomes from one another, they become very much vacuolated by the accumulation of nuclear sap. The membranes of the daughter-nuclei are formed as a result of the nuclear sap coming in contact with the cytoplasm in the manner described for Angiosperms (Lawson, '04).

It is a curious fact to note that no cell-plate formation follows this division. This is shown in Figs. 29 and 30 . The two daughter-nuclei lie freely in the cytoplasm of the mother-cell, one at each end. The interest of this point is its similarity to what occurs in the microsporangium. It will be remembered that in all Gymnosperms no cell-plate is formed immediately after the first division of the microspore-mother-cell in the development of the tetrads, and that cell-plates are only formed after the simultaneous division of the two daughter-nuclei. This is also true for the great majority of the Dicotyledons. The process of tetrad formation here found in Sciadopitys clears up much of the doubt that has existed in regard to the organization and number of cells concerned in the axial row of megaspores among the Coniferales.

The daughter-nuclei resulting from the heterotype division are no sooner organized than preparations for the second division set in. This division is simultaneous, and several preparations showed the twin spindles lying one behind the other in the mother-cell. In regard to their position, these differ from the corresponding spindles in the microsporangium. In the latter case the spindles lie side by side, not one behind the other. This difference has a direct bearing on the position of the cell-plates which are formed after this division. The twin spindles are shown in Fig. $3 \mathbf{I}$ with the reduced chromosomes at the equator, which indicates how exactly simultaneous are the divisions. What follows results in a very curious arrangement, for two cell-plates are now laid down midway between the newly formed daughter-nuclei. Now, as the two spindles lie one behind the other in the mother-cell, with their long axes practically contiguous with one another, we have two pairs of daughter-nuclei in a single row and practically in the same plane. By the formation of the cell-plates the end cell of each pair becomes separated from its neighbour. No plate, however, is formed between the two middle nuclei, and so it comes about that the axial row or tetrads are represented by three cells, the middle one containing two free nuclei. This curious arrangement is clearly demonstrated in Fig. 32 and the four following figures. That this is the regular and normal 
process in the formation of the megaspore tetrads in Sciadopitys I have no doubt, for it was repeatedly demonstrated by a large number of preparations showing every step in the process.

It was stated above that the presence of starch granules was a characteristic of the megaspore-mother-cell, and that previous to the reduction division the starch was rather uniformly distributed throughout the cytoplasm. Just before the second division in the formation of the tetrads, however, the bulk of the starch grains settle in the base of the mother-cell. The result of this is that when the tetrads are formed, the basal cell of the axial row contains much more starch than the other cells (Figs. 32, 33, 34 , and 35). This is an interesting point because this basal cell becomes the only functional megaspore of the axial row. Fig. 33 represents the tetrads of the axial row fully organized, with the basal cell containing an abundance of starch, the middle cell with its two free nuclei, and the top cell of the row with its single nucleus. Fig. 34 shows the axial row where the two free nuclei of the middle cell have shifted their position, demonstrating quite conclusively that no cell membrane separates them. This figure also shows that the nucleus of the top cell is already betraying signs of disorganization.

The basal megaspore of the axial row now enlarges, but its growth is quite slow. Between the stages represented in Figs. 35 and 36 fully four weeks have elapsed. But during this period the two nuclei of the middle cell and the nucleus of the top cell show every evidence of degeneration, and they eventually become quite abortive. The first noticeable change in the functional megaspore is its great elongation down through the tapetal cells, as shown in Fig. $3^{6}$. This is now followed by the formation of a large central vacuole which causes a growth in all directions. Fig. 37 represents a longitudinal section of the functional megaspore and the three abortive megaspores as they appear six weeks after the organization of the axial row. It will be seen that the functional megaspore now consists essentially of a huge vacuole with but a thin film of cytoplasm at the periphery, and a single nucleus at the base. A more highly magnified representation of the last vestiges of the abortive megaspores is shown in Fig. 37.

During all of these stages in the development of the megaspores the number of tapetal cells has increased considerably, so that eventually there are several layers of them surrounding the axial row.

The outline drawing in Fig. $\mathrm{I}_{3}$ is intended to represent the relative position and condition of the two gametophytes in the ovule as they appear at the end of the first year's growth, which closes about the middle of July. It will be seen that the pollen-tube has not penetrated beyond the tissue of the pollen-cushion, and that the large functional megaspore lies embedded in the centre of a large group of nutritive tapetal cells. No further changes take place in either gametophyte until the following spring. 
This postponement of the development of the gametophytes, and consequent delay of fertilization for twelve months, occurs in a number of other Coniferales, but is evidently not peculiar to any particular family. We have it occurring, for instance, in Cephalotaxus (Lawson, '07; Coker, '07), Torreya (Coulter and Land, '05), Pimus (Coulter and Chamberlain, '01 ; Ferguson, '04), and in Sciadopitys. Why this delay should occur in these few genera is hard to explain. The habit may be a special adaptation to meet special conditions of nutrition; on the other hand, it may possibly represent the vestige of a habit of a resting period of the spores at a very early period in the phylogeny of the group when the spores were free. In support of this view, however, there is at present no evidence.

In Sciadopitys no further nuclear changes occur in either the pollentube or megaspore until the following spring. Early in March of the second year, however, the nucleus of the megaspore divides, and this is immediately followed by a large number of free nuclear divisions. The formation of prothallial tissue now proceeds in the usual way. The free nuclei are parietally placed, and after the last simultaneous division, cellwalls are formed between them. There are thus formed the primary prothallial cells which are open on the inside and exposed to the central vacuole. These structures have been sufficiently described and figured for other Coniferales (Coulter and Chamberlain, '01; Ferguson, '04; Coker, '03; Lawson, '04, '07, '09) since their first discovery by Mlle Sokolowa in 1890 .

The primary cells now rapidly elongate and encroach upon the central vacuole after the manner already described for the Abietineae, Cupressineae, and other families. Cross-walls are now formed, and a considerable amount of cellular prothallial tissue is produced before the ingrowing cells meet in the middle and occupy the space of the central vacuole.

During the organization of the prothallial tissue there is developed a distinct and thick megaspore membrane. Its structure is very like that of Pinus, but not quite so thick. It has a distinct fibrillar exospore, and is uniformly thick except in the region of the archegonium, where it tapers out and becomes quite thin. A sectional view of a part of the membrane is shown in Fig. 39. (See Thomson, 1904.)

\section{The Archegonia.}

The archegonia originate as superficial cells, and make their appearance early in April at the apex of the prothallium before the permanent tissue of the latter has been completely organized. The original initial cell was not positively identified; probably on account of its similarity to the ordinary prothallial cells. The first stage observed was after the first division of the initial cell, showing a single neck-cell and a somewhat larger cell below, which develops into the central cell. In Fig. 40 is represented 
a little later stage, where the first neck-cell has divided into two and the central cell has enlarged to about twice its original size. It seems to be the rule among the Coniferales that the archegonia originate as superficial cells, but there are exceptions, as in Sequoia (Lawson, '04) and Widdringtonia (Saxton, '09), where some at least of the archegonia originate deep in the prothallial tissue.

The nourishing jacket cells become differentiated quite early. In the very young stages they look very like the young central cell. They were frequently mistaken for archegonial initials. These cells, although they continue to multiply in number until the archegonium is mature, do not show any increase in size. Those surrounding the very young central cell presented the same dimensions and appearance as those associated with the more mature egg-cell.

The number of archegonia developed varied from four to six, four being the number more commonly met with. They were always found situated at the apex of the prothalliurn, forming a single group, and their position in regard to one another is like that of Pinus, Abies, Psendotsuga, and Cephalotaxus, the individuals being separated by sterile prothallial tissue. In the mature state they are never as wide as the archegonia of the Abietineae, being rather narrow, long, tapering structures more nearly resembling those of Cephalotaxus. Each archegonium is surrounded by its own single layer of nourishing jacket cells.

The young central cell enlarges very rapidly and elongates in a direction towards the centre of the prothallium. During the growth of the central cell its nucleus always remains directly under the neck-cells. The cytoplasm is quite coarsely granular and contains a number of small vacuoles. An early stage is shown in Fig. 4I. The enlargement and downward growth of the cell continues, and, as shown in Fig. 42, the cytoplasm becomes charged with granules of food substance, evidently taken in through the jacket cells. As growth proceeds the vacuoles become larger and much more numerous, until, as illustrated in Fig. 43, the entire cell cavity takes on a frothy appearance in identically the same manner as it does in Cephalotaxus, Pseudotsuga, Picea, and Abies (Miyake, '03 ; Lawson, '07). As more food substance gathers in the cytoplasm of the cell, the vacuoles appear to flow together, finally forming a single large one some distance behind the nucleus. Here, again, the archegonium differs from that of the Abietineae, for among the latter there is no large vacuole, either in the central cell or the egg-cell.

As shown in Figs. 40, 4I, and 42, during all the early stages of the archegonium the neck-cells are superficially placed in regard to the apical surface of the prothallium. This condition, however, is soon changed, for all of the sterile tissue at the apex grows forward for a considerable distance, leaving an open canal leading to the neck of each archegonium. These 
canals or archegonial chambers occur in all Coniferales, where the individual archegonia are isolated from one another, but as a rule they are quite shallow. In Sciadopitys, however, they are very deep-so deep that the mature archegonia eventually find themselves buried in the prothallial tissue a considerable distance behind the apex, as shown in Figs. 44 and 48 . Stages in the development of the archegonial chamber may be seen in Figs. 42, 43, and 44 .

Meantime, the neck-cells have divided repeatedly, forming a single tier. At maturity these cells partly separate from one another on the outer side and spread out in a fanlike fashion. Directly under the neck-cells the central cell is quite narrow, but broadens out rather abruptly, as shown in Figs. 43 and 44. There is thus formed a narrow pocket near the neck, and in this pocket the nucleus remains throughout the developmental stages of the central cell.

When the latter reaches its full size, the nucleus undergoes a division which results in the organization of the egg nucleus and the ventral canal nucleus. The spindle is formed directly under the neck, as shown in Fig. 45. A later stage of this mitosis is shown in Fig. 46 , where the chromosomes are at the poles. A careful search was made for a ventral canal cell membrane, but although all stages of this mitosis were observed, no such membrane could be found. I am quite convinced that a cell-wall is not formed after this division. A considerable number of archegonia showed the condition represented in Fig. 47, where the ventral canal nucleus was found lying freely in the cytoplasm just above the egg nucleus. It will be remembered that among the Abietineae a definite membrane is formed which separates the ventral canal cell from the egg-cell. In a previous memoir (Lawson, '07 and '09) I have called attention to the probable phylogenetic importance of this. In the present case of Sciadopitys the absence of this membrane becomes interesting when we couple it with the fact that the functionless prothallial cells of the pollen are also absent. It would almost seem that there had been a simultaneous elimination of these vestigial structures.

The egg nucleus and ventral canal nucleus are no sooner formed than they both undergo a change. The latter immediately disorganizes and functions no further, while the former enlarges enormously and moves down and takes up its position in the centre of the cell. Mature archegonia ready for fertilization are shown in Figs. $44,4^{8}$, and 49.

\section{Fertilization.}

As in the Abietineae and Cephalotaxus, the arrangement and grouping of the archegonia are such that it is possible for the contents of one pollentube to fertilize but a single archegonium. After passing through the nucellar tissue, the pollen-tube enters one of the long archegonial chambers, 
and continues its growth until the neck-cells are reached. Meantime, the body-cell descends and takes up a position in the tip of the tube, and here undergoes division, giving rise to the two sperm nuclei. The tip of the tube apparently passes between the neck-cells, and its contents are discharged into the upper cytoplasm of the egg. The course of the tube in its passage through the archegonial chamber is shown in Fig. 48.

Before and during the fertilization period the cytoplasm of the egg becomes heavily charged with coarse granules of food substance and numerous large so-called 'proteid vacuoles'. Meantime, the nourishing jacket cells undergo a curious modification to which Arnoldi ('01) has called attention. The inner wall of these cells - that is, the wall lining the egg-cell-becomes strengthened by coarse, irregularly branched, reticulated thickenings. These thickenings project beyond the surface of the cells, and in sections may be seen extending into the cytoplasm of the egg. It would seem that there was a necessity for strengthening these walls without interfering with the transfusion of substances from the jacket cells into the egg. The thickenings were evidently not of cellulose, for they stained black after being treated with Flemming's triple stain. They are probably of a chitinous nature. In surface view they appear as in Fig. $5^{\mathrm{I}}$.

When the egg-cell is ready to be fertilized its nucleus lies in the centre of the cell just above the vacuole, as indicated in Figs. 44 and 48 . The relative size of the egg nucleus and sperm nucleus may be observed in Fig. 49, the former being many times the size of the latter. Although the two male nuclei enter the egg, only one of them-presumably the larger one--unites with the female nucleus. The actual fusion of the sex nuclei was not observed, but the immediate result is shown in Fig. $5^{\circ}$. Here we see the first spindle of the sporophyte organized within the boundary of the membrane of the egg nucleus.

\section{The EMbryo.}

The position of the first cleavage spindle seemed to vary within the area of the fusion nucleus. The long axis of the spindle was sometimes found parallel to the long axis of the archegonium; in others it was at right angles to this position. In Fig. $5 \circ$ it is lying obliquely. There seemed to be no definite polarity in this respect.

Before this first mitosis is complete the membrane of the fusion nucleus fades and finally disappears, leaving the two first free nuclei of the proembryo in the cytoplasm just about the middle of the egg. A sufficient number of stages of the spindle were found to observe with fair accuracy the number of the chromosomes, which were found to be sixteen. I was, however, unable to distinguish a male and female group which have been described by Miss Ferguson ('04) in the case of Pimus.

The first two free nuclei remain in the middle region of the egg until 
the second mitosis takes place, which follows closely upon the first. The resulting four free nuclei now pass to the base of the archegonium before the third series of divisions occur (Fig. 52). During their passage to the base all four nuclei enlarge. The next stage observed was that represented in Fig. 53, where another division has taken place just before the base of the archegonium has been reached. The next division results in the formation of cell-walls between the nuclei. As in the Pinus and other Abietineae, there are three tiers of cells and one tier of free nuclei constituting the pro-embryo. The middle tier of cells develops into suspensors and the end tier is carried forward in the ordinary way. Before the elongation of the suspensors, however, the cells of the end tier divide repeatedly, forming three or four rows which taper to a point. Fig. 54 represents an older stage where the suspensors are very much elongated and pushing forward a large group of embryo cells at the end. Arnoldi ('01) describes an additional stage where buds and smaller secondary suspensors are given off from these cells. This I was unable to find. But this was probably because I did not collect material later than July 7 , and the stage of development at that date is represented in Fig. 54. I hope in another season to confirm this interesting later development of the embryo described by Arnoldi.

On the whole the embryo of Sciadopitys is rather unique; it does not bear a close resemblance to either the Abietineae, Cupressineae, or Taxaceae.

\section{SUMMARY.}

At pollination the microspores have already germinated. Each one has a very thick exine and a thin inner wall which surround two cells, the generative cell and the tube cell.

At this time the integument of the ovule projects very slightly above the level of the nucellus in such a manner as to form a wide but shallow micropyle.

The upper part of the nucellus becomes differentiated into a loose tissue of large thin-walled cells for receiving the pollen. This structure has been called the pollen-cushion.

As soon as the pollen-grains have been received they send out tubes which penetrate the soft tissue of the cushion.

The generative cell now divides, giving rise to a large spherical bodycell and free stalk-nucleus.

At the end of the first season's growth, which closes about the middle of July, the male gametophyte contains three nuclear structures, viz. the tube-nucleus, the stalk-nucleus, and the body-cell. No further nuclear changes take place until the following spring.

In June of the next year the body-cell descends towards the tip of the pollen-tube, which, meantime, has entered an archegonial chamber. 
The division of the body-cell nucleus takes place immediately over the neck-cells of an archegonium, and this gives rise to two male nuclei of unequal size. Definite male cells are not formed, but merely male nuclei, as in the Abietineae.

The contents of the tip of the pollen-tube are discharged into a single archegonium.

A single megaspore-mother-cell is organized, whose nucleus undergoes a heterolytic mitosis, and resulting in the reduction in the number of chromosomes.

The sporophyte has sixteen chromosomes and the gametophytes eight.

After the reduction division of the megaspore-mother-cell nucleus no cell-plate is formed. The two daughter-nuclei lie freely in the cytoplasm. The first step in the formation of the megaspore tetrads is the same as that of the microspore tetrads.

The division of the daughter-nuclei occurs simultaneously, but the spindles lie one behind the other, and not side by side as in the microsporangium.

As a result of this second division the axial row of megaspores consists of three cells, the middle one of which contains two free nuclei.

The basal cell of the axial row becomes the functional megaspore, the other two become abortive.

The functional megaspore becomes very large, and contains a huge central vacuole, but no further germination takes place until March of the following year.

A distinct tapetum, consisting of two or three layers of large nutritive cells, is organized, and completely envelops the germinating megaspore. The tapetum is evidently of archesporial origin.

The megaspore remains unicellular until March of the second season's growth.

The nucleus now divides, and this is immediately followed by numerous free nuclear divisions.

The resulting free nuclei become distributed in the parietally-placed cytoplasm, and the first or primary prothallial cells are formed by the development of cell-walls.

The organization of the permanent prothallial tissue is brought about in the manner described for the majority of the Coniferales.

The archegonia originate at the apex of the prothallium. They are four or six in number, and each is enveloped by its own single layer of nourishing jacket cells.

During the fertilization period the inner walls become curiously modified by heavy, reticulated, chitinous-like thickenings.

The archegonia are isolated from one another by sterile tissue, and each is provided with a deep archegonial chamber. 
A ventral canal nucleus is formed, but no cell membrane separates it from the egg.

The mature egg nucleus is many times the size of either of the male nuclei.

The union of the sex nuclei occurs in the middle region of the egg, and the first segmentation spindle is immediately formed within the membrane of the fusion nucleus.

The first division of the sporophyte is immediately followed by a second, forming four free nuclei in the pro-embryo.

These now sink to the base of the archegonium, and undergo further divisions.

Eventually the pro-embryo consists of three tiers of cells and one tier of free nuclei. The middle tier of cells become the suspensors, and the embryo proper consist of a large mass of cells, at least sixteen in number.

\section{LITERATURE CITED.}

ARNoldi, W. ('01) : Beiträge zur Morphologie einiger Gymnospermen: V. Weitere Untersuchungen iiber die Embryologie in der Familie der Sequoiaceen. Bull. Soc. Imp. Nat. Moscou, I 90 or.

Blackman, V. H. ('98): On the Cytological Features of Fertilization and Related Phenomena in Pinus silvestris, L. Phil. Trans. Roy. Soc., cxc, p. 395.

Chamberlain, C. J. ('06): The Ovule and Female Gametophyte of Dioon. Bot. Gaz., xlii, p. $321,1906$.

Coker, W. C. ('02): Notes on the Gametophytes and Embryo of Podocarpus. Bot. Gaz., xxxiii, p. 89 .

('03): The Gametophytes and Embryo of Taxodium. Bot. Gaz., xxxvi, pp. I-27 and II $4-40$.

Coulter, J. M., and Chamberlain, C. J. ('01): Morphology of Spermatophytes, Part. I. New York, 1901 .

Coulter, J. M., and LAND, W. J. G. ('05): Gametophytes and Embryo of Torreya taxifolia. Bot. Gaz., xxxix, p. 16I, I905.

Ferguson, M. C. ('01): The Development of the Pollen-tube and the Division of the Generative Nucleus in certain species of Pinus. Ann. Bot., xv, p. I93. Bot., xv, p. 435 .

Lawson, A. A. ('03): On the Relationship of the Nuclear Membrane to the Protoplast. Bot. Gaz., $\mathrm{xxxv}$, no. v, p. $3 \circ 5,1903$.

('04): The Gametophytes, Archegonia, Fertilization, and Embryo of Sequoia sempervirens. Ann. Bot., xviii, no. lxix, p. I, 1904 .

('04): The Gametophytes, Fertilization, and Embryo of Cryptomeria japonica. Ann. Bot., xviii, no. $1 \times x i, 1904$.

('07): The Gametophytes, Fertilization, and Embryo of Cephalotaxus drupacea. Ann. Bot., xxi, no. lxxxi, 1907 .

('07): The Gametophytes and Embryo of the Cupressineae with special reference to Libocedrus decurrens. Ann. Bot., xxi, no. 1xxxii, 1907 .

no, $\mathrm{xc}, \mathrm{r} 909$.

Mryake, K. ('03): On the Development of the Sexual Organs and Fertilization of Picea excelsa. Ann. Bot., xvii, p. 66. 
Miyake, K. ('03): Contribution to the Fertilization and Embryogeny of Abies balsama. Beihefte zum Bot. Cent., xiv, p. $\mathrm{I} 34,1903$.

MURrill, W. A. ('00): The Development of the Archegonium and Fertilization in the Hemlock Spruce (Tsuga canadensis). Ann. Bot., xiv, p. 583 .

Robertson, A. ('04): Spore formation in Torreya Californica. New. Phyt., iii, p. I33, r904.

('04): Studies in the Morphology of Torreya Californica. New Phyt., iii, p. 205 , I 904.

Saxton, W. T. ('09): Preliminary Account of the Ovule, Gametophyte, and Embryo of Widdring. tonia cupressoides. Bot. Gaz., xlviii, no. iii, p. I66, 1909 .

Sokolowa, Mlle C. ('90): Naissance de l'endosperme dans le sac embryonnaire de quelques Gymnospermes. Bull. Soc. Imp. Nat. Moscou, I 890 (I89I), p. 446.

Thomson, R. B. ('05): The Megaspore-membrane of the Gymnosperms. Univ. Toronto Studies, Biol. Series, iv. 1905 .

\section{EXPLANATION OF FIGURES IN PLATES XXIX-XXXI.}

\section{Illustrating Dr. Lawson's Paper on Sciadopitys.}

All figures were drawn with the aid of the camera lucida. The following oculars and objectives were used :-

Figs. I, 2, 3, 4, 5, 16, 17, 18, 19, 20, 21, 22, 23, 24, 25, 26, 27, 28, 29, 30, 31, 32, 33, 34, 35, $3^{6}, 3^{8}$, Zeiss oc. 8 , obj. $\frac{1}{12}$ oil imm. $\quad x$ about 1600 .

Figs. ${ }_{14}, \mathrm{I} 5,45,46,47,52,53,54$, Zeiss oc. 4 , obj. C. $\times$ about 250.

Figs. 40, 4I, 42, 43, 44, 48, Zeiss oc. 4 , obj. A. $\times$ 100.

Figs. Io, I1, I 2, 37, 39, Zeiss oc. 4, obj. $\frac{1}{12}$ oil imm. $\times$ about 1000.

Figs. $8,9,50$, Zeiss oc. 8 , obj. C. $\times$ about 450 .

Figs. 13, 49, Zeiss oc. 8, obj. A. xabont 160.

Fig. I. A cross section of a microspore some time before pollination, showing the single centrally situated nuclear considerably enlarged and preparing for mitosis. April 22.

Fig. 2. The same at a later stage, showing the spindle of the first division of the microspore nucleus. This and the following two figures shows the characteristic hard thick exine tapering out and becoming very thin at one side. April 22.

Fig. 3. The same, showing the chromosomes at the poles of the spindle. April 22.

Fig. 4. The same, showing the daughter-nuclei fully organized and separated from one another by a very thin cell membrane. April 22.

Fig. 5. A section of a microspore a few days after pollination, as seen at the surface of the pollen-cushion of the nucellus. Here the exine has been completely thrown off, and the spore itself has become elongated and considerably enlarged. The generative and tube-cells are fully developed. April 24.

Fig. 6. A longitudinal section of a young ovule taken about three or four weeks after pollination, showing the integument and nucellus with the pollen-grains collected on the surface of the pollencushion. The micropyle has not yet been closed. May 25 .

Fig. 7. A longitudinal section of the upper part of the nucellus, showing the nature of the highly differentiated tissue of the pollen-cushion, into which the pollen-tubes are penetrating. July I 7 .

Fig. 8. A longitudinal section of a pollen-tube after the division of the generative cell, showing the body-cell and the stalk-nucleus still in the spore region of the tube. June 17 .

Fig. 9. The same, showing the relative positions of the three essential structures of the tube. The body-cell has remained within the spore region of the tube. The stalk and tube nuclei have descended into the tube for a considerable distance, the latter in advance of the former. June 17 .

Fig. I0. The same, more highly magnified to show the structure of the nuclei and the presence of large masses of starch grains in the cytoplasm of the tube. July 17 . 
Fig. II. A section of a pollen-tube taken just eleven months later than that shown in Fig. IO. Here the body-cell has descended into the tube and is situated near the tip. Its nucleus is very much enlarged in preparation for mitosis. June $\mathbf{1} 9$.

Fig. I 2. A longitudinal section of a body-cell, showing the result of the division of the bodynucleus. The two male nuclei appear in sectional view to be of unequal size, but lie freely within the cytoplasm of the body-cell with no membrane separating them from one another. June $\mathbf{I}_{5}$.

Fig. I3. An outline drawing of a longitudinal section of an ovule.

Fig. I4. A transverse section of the megasporangium, showing the functional megaspore-mothercell embedded in the tapetum. It will also be seen that the sporanginm is connected with the integument at opposite sides of the broadest diameter, giving strength and support to the sporangium region. June 4 .

Fig. 15. A longitudinal section of a megasporangium, showing the position of the large megaspore-mother-cell completely surrounded by two or three layers of tapetal cells. June 4 .

Fig. I6. A longitudinal section to show the relative size of the megaspore-mother-cell to the surrounding tapetal cells. June 3 .

Fig. 17. A megaspore-mother-cell with the nucleus enlarged and preparing for the reduction division. May I2.

Fig. I8. The same at a later stage, showing the chromatin in the form of a tangled spireme and the nuclear cavity considerably enlarged. May $\mathbf{2} 2$. June 3 .

Fig. I9. The same at a slightly later stage, with the chromatin threads more slightly differentiated.

Fig. 20. The same with the chromatin threads thicker, shorter, and more evenly distributed through the nuclear cavity. June 3 .

Fig. 2I. A slightly later stage of the same, with the chromatin in the form of thick granular threads. June 3 .

Fig. 22. The same with the granular chromatin threads still more shortened and thickened. June 3 .

Fig. 23. The same with the chromatin threads so shortened and thickened that this granular nature is much less evident. Definite chromosomes are now formed. June 3 .

Fig. 24. A later stage of the same, showing the double nature of the chromosomes. June 3 .

Fig. 25. A megaspore-mother-cell at the time of the formation of the reduction spindle and showing the form of the heterotype chromosomes. June 4 .

Fig. 26. A megaspore-mother-cell, showing the mature reduction spindle with the chromosomes at the equator. June 4 . June 4 .

Fig. 27. A reduction spindle with the heterotype chromosomes facing the equatorial plate.

Fig. 28. A transverse section of a megaspore-mother-cell with the heterotype chromosomes at the equatorial plate. June 4 .

Fig. 29. A megaspore-mother-cell in the later phase of the reduction division, with the chromosomes at the poles of the spindle, and before the organization of the daughter-nuclei. June 4 .

Fig. 30. The same a little later, with the daughter-nuclei organized, and the chromosomes very much vacuolated and giving a reticulated appearance. There is no trace of a cell-wall separating the danghter-nuclei from one another. June 4.

Fig. 3I. A mother-cell, showing the simultaneous division of the daughter-nuclei. The twin spindles lie one above the other with the chromosomes, which are clearly reduced in number from the equatorial plates. June 4 .

Fig. 32. The result of the second division of the mother-cell. Here it will be seen that cell-walls are formed after this division, and, as a result of this, these cells constitute an axial row. But in consequence of there being no cell-wall formed after the first division, and two cell-walls formed after the second division, we find the middle cell of the axial row containing two free nuclei, and the two end cells one each. June 4.

Fig. 33. A somewhat later stage of the same, showing the definite cell-walls separating the two end cells of the axial row from the middle cell, and the latter containing two free nuclei. It will be noted also that starch is much more abundant in the basal cell of the axial row than in the other two. June 4.

Fig. 34. A still later stage of the same, showing a shifting of the two free nuclei of the middle 
cell, which proves quite clearly that no membrane separates them from one another. It may be seen also that the nucleus of the top cell of the axial row shows signs of disorganization. June 4 .

Fig. 35. The same at a later stage. Here we see the two nuclei of the middle cell and the nucleus of the top cell showing signs of disorganization, and the basal cell considerably enlarged, with its nucleus in a normal active condition. June 4.

Fig. 36. A longitudinal section of the axial row. It will be seen that the basal cell has enormously enlarged and becomes really the functional megaspore. The middle and top cells show no growth whatever, and their nuclei are very much disorganized. June I 2.

Fig. 37. A longitudinal view of the very large functional megaspore and the three abortive, more or less disorganized, functionless spores at the top. It will be noted also that the functional megaspore consists for the most part of a large central vacuole, and the relatively small amount of cytoplasm present is parietally placed. June I 9 .

Fig. 38. A more highly magnified view of the three abortive megaspores. The three nuclei become crowded together and altogether difficult to recognize as nuclei. The two free nuclei of the middle cell become flattened against one another. June I9.

Fig. 39. A part of the megaspore membrane as seen in longitudinal section. June 19.

Fig. 40. A longitudinal section of a very young archegonium, which at this stage consists of a central cell and two neck-cells. April.

Fig. 4I. The same, showing the enlargement of the central cell and the differentiation of the jacket cells. May $\mathbf{I}$.

Fig. 42. A longitudinal section of two young archegonia, showing the great increase in length and breadth of the central cell. May I 5 .

Fig. 43. The same at a later stage of development, when the cytoplasm of the central cell has become very much vacuolated, and the sterile tissue at the apex of the prothallium has grown forward, leaving the archegonium behind, and forming a single archegonial chamber leading to the neck-cells of each archegonium. May 25.

Fig. 44. Two mature archegonia ready for fertilization, each containing a large central vacuole in the rear of the egg nucleus. June 19.

Fig. 45. The nucleus of the central cell in process of division. The spindle is formed directly under the neck-cells. June I 5 .

Fig. 46. The ventral canal spindle with the chromosomes at the poles. June I 5 .

Fig. 47. The neck region of an archegonium, showing the relative size and position of the ventral canal nucleus and egg nucleus soon after they are formed. June $\mathrm{I}_{5}$.

Fig. 48. A longitudinal section of the apex of the nucellus and upper part of the prothallium, to show the penetration of the pollen-tube through the nucellar tissue and archegonial chamber to the neck-cells of the archegonium. June 19.

Fig. 49. A longitudinal section to show the relative size of the two male nuclei as they lie in the upper cytoplasm of the archegonium immediately after their discharge from the pollen-tube through the neck-cells. June 27 .

Fig. 50. A longitudinal section of the fusion-nucleus immediately after fertilization, to show the position and form of the first sporophyte-spindle within the confines of the membrane of the egg nucleus. June 29 .

Fig. 51. A surface view of the chitinous-like reticulated thickenings on the inner walls of the jacket cells during the period of fertilization. June 29 .

Fig. 52. A longitudinal section of a pro-embryo, showing four free nuclei descending to the base of the archegonium. June 29.

Fig. 53. The same at a later stage, to show the arrangement of the free nuclei in three tiers just previous to the formation of walls between them. July 2 .

Fig. 54. A later stage in the development of the embryo after the elongation of the suspensors. The embryo proper at this time consists of several layers of cells which are carried forward into the prothallial tissue by the elongated suspensors. July 7 . 


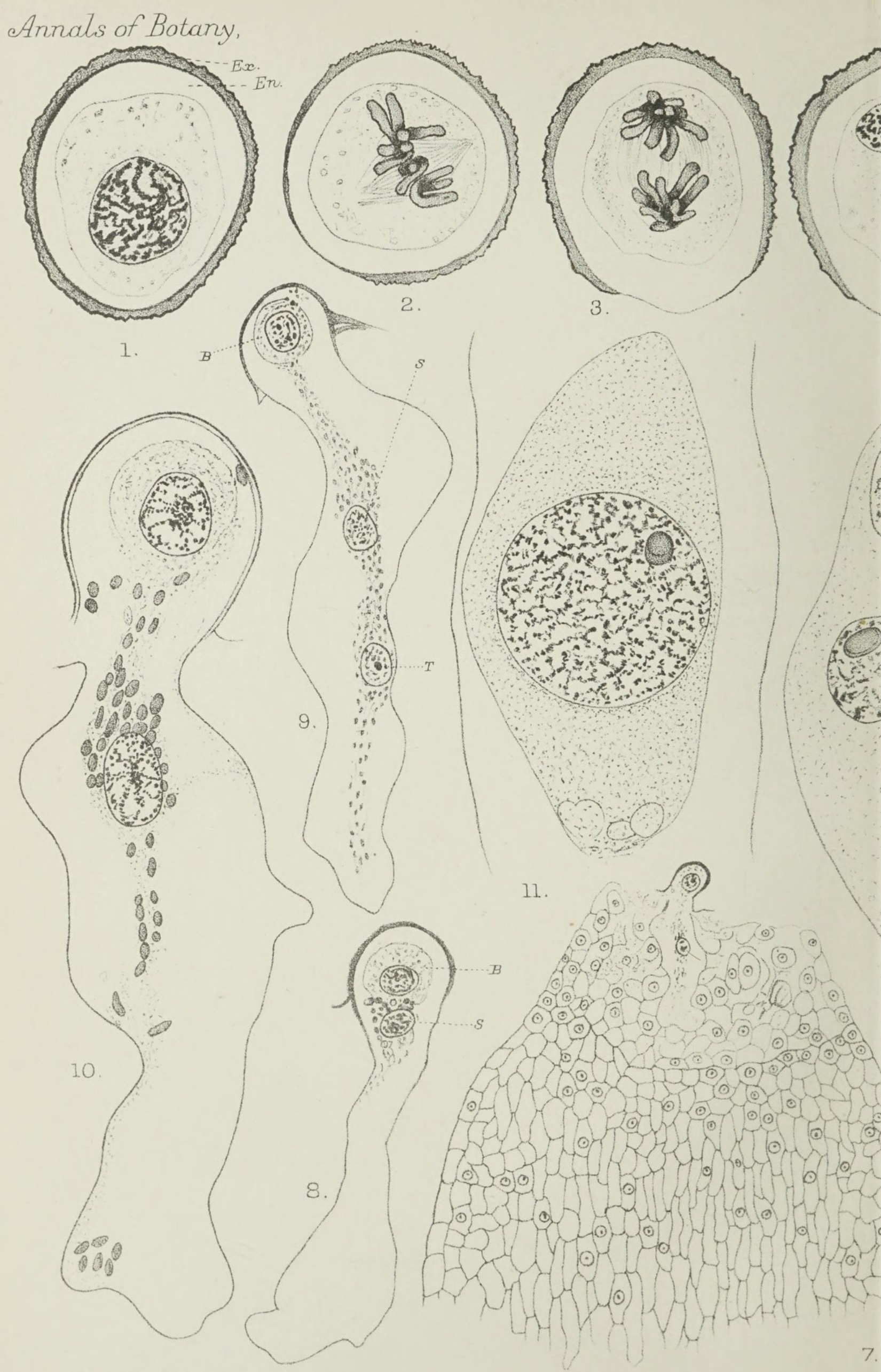

LAWSON - SCIADOPITYS. 
Annals of Botany,

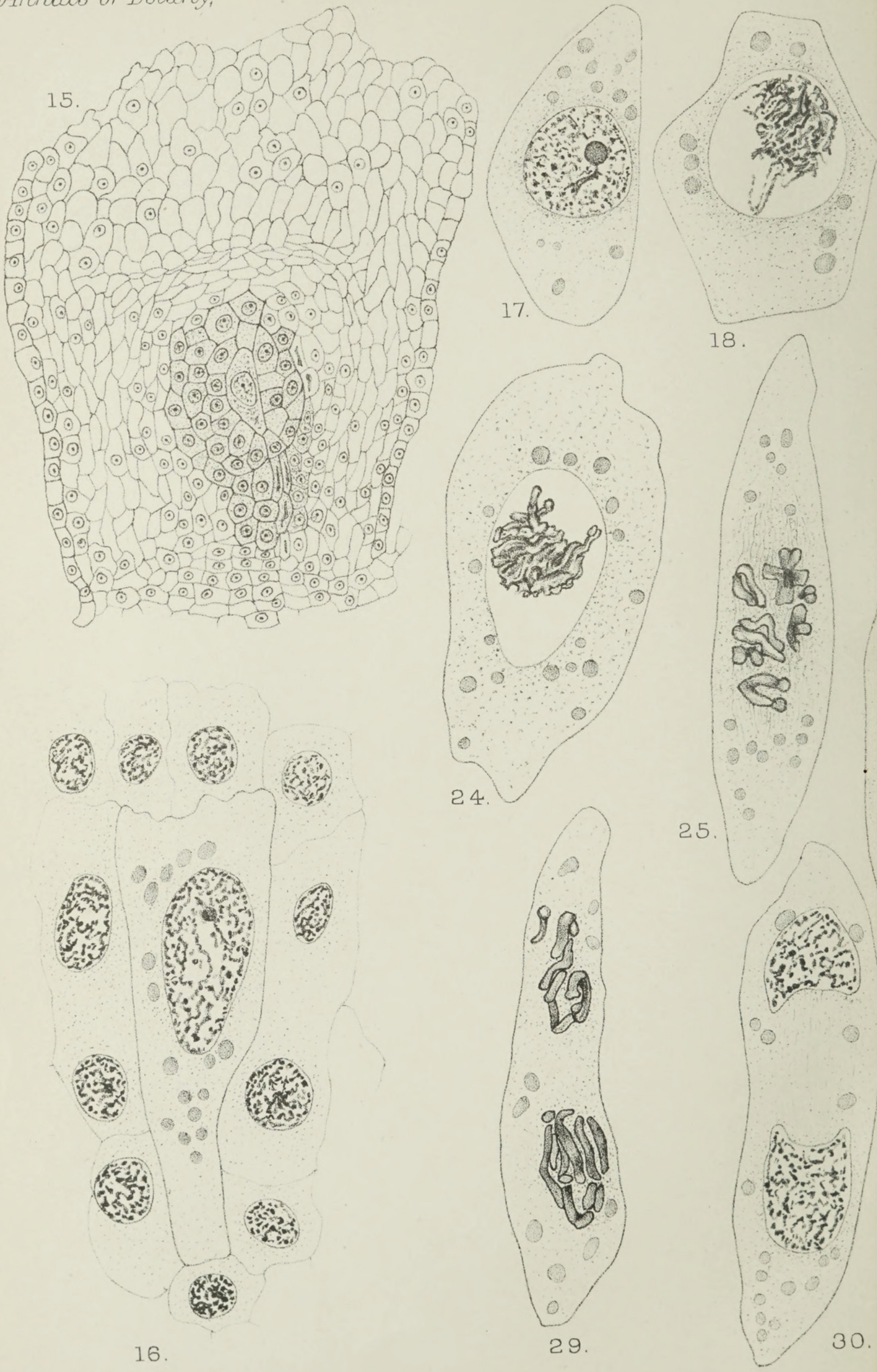




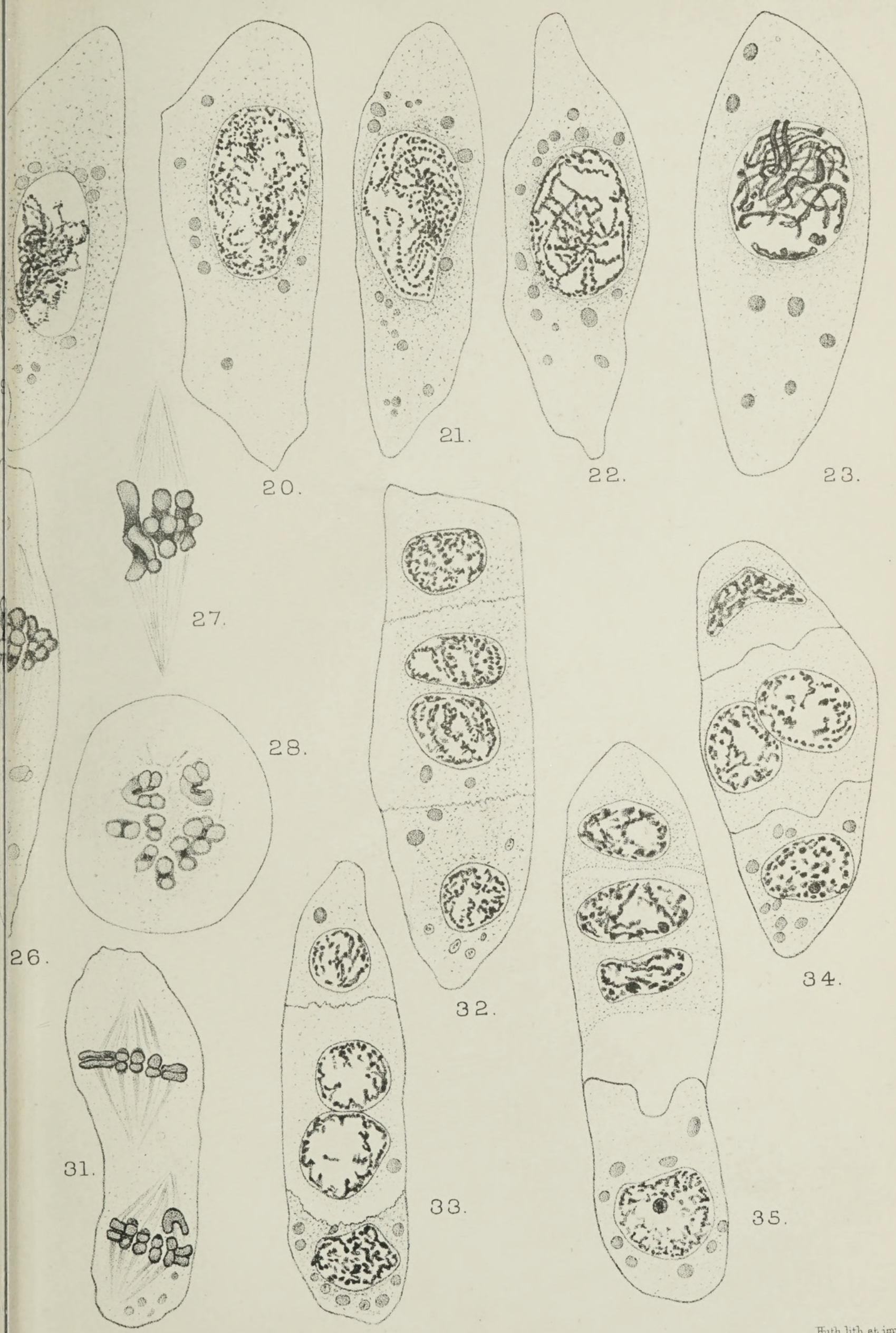


Annals of Botany,

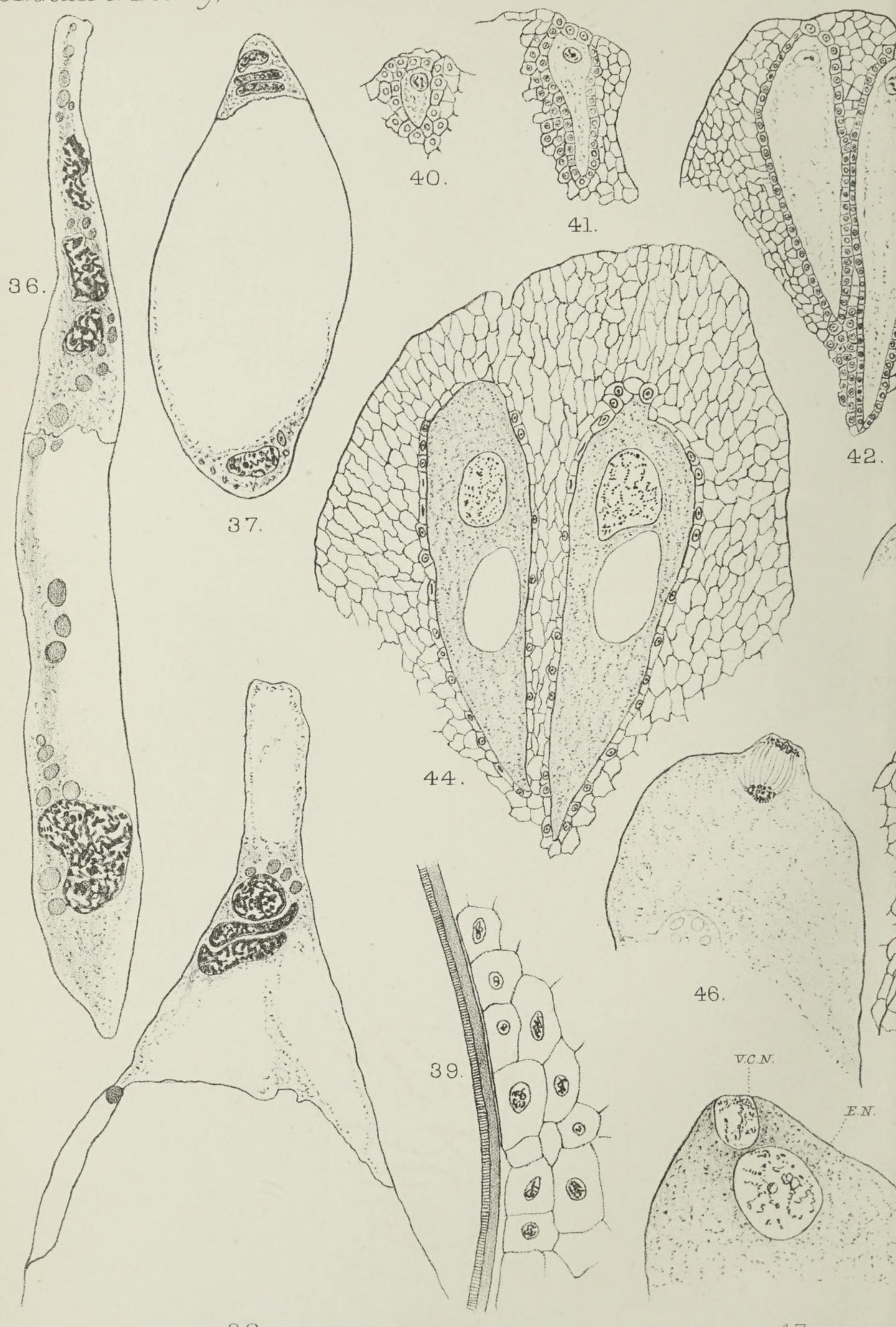

38. 


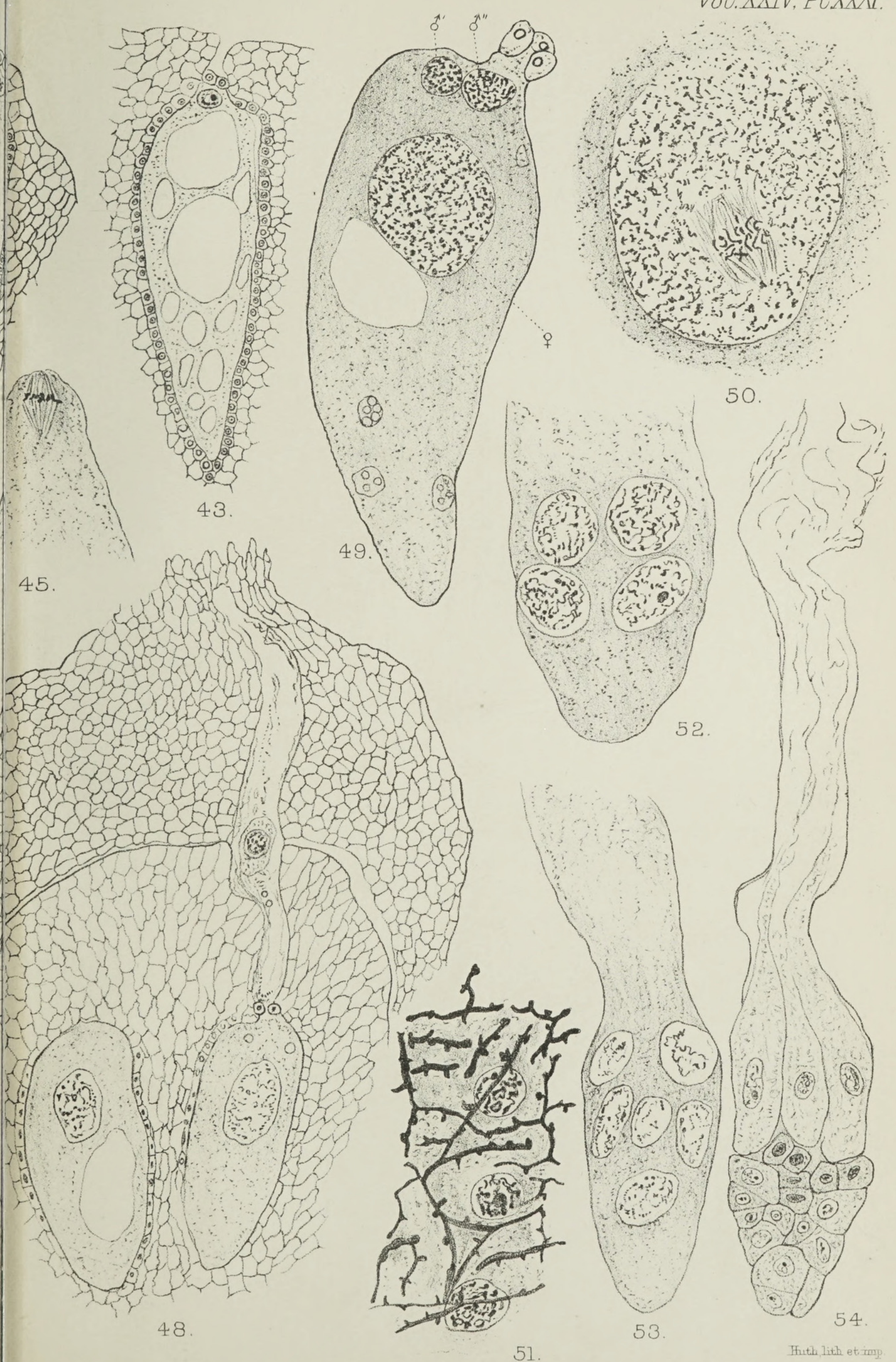




\section{$2 \mathrm{BHL}$ Biodiversity Heritage Library}

Lawson, Abercrombie Anstruther. 1910. "The gametophytes and embryo of Sciadopitys verticillata." Annals of botany 24, 403-421. https://doi.org/10.1093/oxfordjournals.aob.a089276.

View This Item Online: https://www.biodiversitylibrary.org/item/262605

DOI: https://doi.org/10.1093/oxfordjournals.aob.a089276

Permalink: https://www.biodiversitylibrary.org/partpdf/319784

\section{Holding Institution}

New York Botanical Garden, LuEsther T. Mertz Library

\section{Sponsored by}

BHL-SIL-FEDLINK

\section{Copyright \& Reuse}

Copyright Status: Public domain. The BHL considers that this work is no longer under copyright protection.

This document was created from content at the Biodiversity Heritage Library, the world's largest open access digital library for biodiversity literature and archives. Visit BHL at https://www.biodiversitylibrary.org. 